\title{
Emigração e multiculturalidade na prática clínica
}

Leonor Prata*

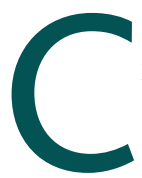

omo resultado das modificações que ocorreram, do ponto de vista laboral, social e político nas últimas décadas, e, em particular nos anos 90, em todo o mundo, Portugal é, actualmente, um país de imigrantes.

De facto, conforme referido no Plano para a Integração dos Imigrantes - Resolução do Conselho de Ministros, ${ }^{1}$ os imigrantes constituíam, em 2007, 9\% da população activa e 4,5\% da população nacional.

Esta expressiva presença dos imigrantes condiciona, naturalmente, mudanças na sociedade portuguesa e constitui, no caso particular da saúde, um desafio para as organizações e para os prestadores de cuidados que nelas trabalham.

No que à saúde diz respeito, podem considerar-se várias questões, merecedoras de reflexão:

- a acessibilidade dos imigrantes, e, em especial, dos que estão em situação ilegal, aos cuidados de saúde;

- o nível de conhecimento, por parte dos imigrantes, dos seus direitos, em relação à saúde;

- a interferência dos aspectos culturais na saúde e no acesso e modo de utilização dos cuidados de saúde;

- as dificuldades sentidas pelos profissionais de saúde, ao lidar com pessoas que, por vezes, se encontram em situação de grande vulnerabilidade, física, psicológica, social e económica, em relação com a própria condição de imigrantes, o que pode condicionar a sua saúde;

- obstáculos encontrados ao prestar cuidados a pessoas de outras culturas: encontram-se barreiras ao nível da língua, diferentes concepções sobre saúde, doença e corpo, constrangimentos em relação com a cultura e a religião;

- as expectativas dos emigrantes, em relação aos técnicos e aos cuidados de saúde que lhes são prestados, por comparação com os sistemas de saúde dos seus países de origem e em relação com as suas con-

*Assistente Graduada de Medicina Geral e Familiar.

C.S Reboleira - Ext. Damaia cepções de saúde e doença;

- a existência de poucos estudos que caracterizem os problemas de saúde dos emigrantes e a eventual existência de diferenças, nos indicadores de saúde, em geral, e em relação a determinadas patologias específicas (p.e., a diabetes), por comparação com a população não imigrante;

- a falta de formação dos profissionais de saúde na área da multiculturalidade. A aquisição de conhecimentos nesta área e a adopção de abordagens adaptadas às especificidades destes utentes poderá facilitar o trabalho dos profissionais, com melhores resultados;

- a necessidade de definição, pela sociedade e em políticas de saúde, do grau e tipo de modificações que devem ser feitas nos serviços de saúde, no que respeita à integração de diferentes aspectos culturais um exemplo é o da circuncisão masculina, por motivos estritamente culturais. Deve esta intervenção ser feita no Serviço Nacional de Saúde? E que posição deve ter na lista de espera? Se não for feita, do ponto de vista cirúrgico, no contexto adequado, poderá ser executada noutros contextos, com menos cuidados, expondo os que a ela são submetidos a riscos desnecessários para a sua saúde? Devem os hospitais providenciar, para além de um capelão católico, que habitualmente existe, um representante de outras religiões, se assim for solicitado? Podem ser respeitados os desejos, impostos por certas religiões, de o atendimento médico ou de enfermagem ser realizado por um profissional do mesmo sexo do doente?

- finalmente, não serão de esquecer os imigrantes profissionais de saúde e os problemas que estes encontram, ao terem que se adaptar, não só à cultura portuguesa, mas a um sistema de saúde que é, por vezes, muito diferente do dos seus países de origem.

Neste dossier, procuram discutir-se alguns aspectos desta área tão vasta. É feita uma caracterização da imigração em Portugal, sob vários pontos de vista. Abor- 
dam-se, depois, os problemas de saúde dos emigrantes, tendo em atenção a idade, o sexo e a fase da vida. Exploram-se alguns aspectos culturais, que condicionam os comportamentos sexuais e de que o Médico de Família deve ter conhecimento. Finalmente, são discutidas algumas das dificuldades que se apresentam ao profissional de saúde que trabalha neste contexto.

Em Portugal, existem poucos estudos abordando a relação entre a emigração, a multiculturalidade e a saúde. Esta constitui, assim, uma área a explorar, em termos de intervenção na comunidade e de investigação. Pelo contexto de proximidade com estas populações em que os Médicos de Família trabalham, poderão estar numa posição privilegiada para o fazer.

Muito mais haveria para abordar, mas esperamos que a leitura destes artigos possa informar e esclarecer os Médicos de Família e ajudá-los a sentir maior segurança na sua prática clínica.

Boa leitura!

\section{REFERÊNCIAS BIBLIOGRÁFICAS}

1. Plano para a Integração dos Imigrantes - Resolução do Conselho de Ministros n 63-A/2007, ACIDI, I.P.

\section{ENDEREÇO PARA CORRESPONDÊNCIA}

Leonor Prata

E-mail: leonor.prata@rpcg.apmcg.pt 